\title{
IMPLEMENTASI SISTEM PELATIHAN E-LEARNING TERHADAP KEPUASAN PEGAWAI KEMENTERIAN KELAUTAN DAN PERIKANAN MELALUI APLIKASI E-MILEA
}

\author{
Oleh: \\ Wahyu Yulianto \\ Balai Diklat Aparatur Kementerian Kelautan dan Perikanan \\ Program Studi Manajemen - STIE DR KHEZ Muttaqien Purwakarta \\ Email: wahyuyuliantokkp@gmail.com
}

\begin{tabular}{l}
\hline Article Info \\
\hline Article History : \\
Received 29 July - 2020 \\
Accepted 20 August - 2020 \\
Available Online \\
O7 Sept - 2020
\end{tabular}

Keyword :

Implementation E-

Learning, Information

Quality, Service Quality,

System Quality, User

Satisfaction.

\section{PENDAHULUAN}

Corona virus disease atau covid-19 sebagai pandemi telah dideklarasikan oleh WHO (World Health Organization) sejak Maret 2020 (WHO 2020). Pandemi ini juga telah menyerang Indonesia secara masif sejak Maret 2020. Pandemi covid-19 berdampak hampir pada semua aspek kehidupan masyarakat Indonesia, tidak hanya berdampak pada kehidupan sosial dan ekonomi tetapi juga berdampak terhadap sistem pendidikan. Peraturan pemerintah tentang pembatasan sosial berskala besar (PSBB) yang tertera dalam Peraturan Pemerintah Nomor 21 Tahun 2020 (BPN 2020) mengakibatkan penyelenggaraan pendidikan dan pelatihan (diklat) oleh Balai Diklat Aparatur Kementerian Kelautan dan Perikanan (BDA KKP) harus disesuaikan dengan situasi yang terjadi. Hal ini dikarenakan 
BDA KKP memiliki target pelatihan melalui $e$ learning yang semula 1.080 aparatur sipil negara (ASN) di KKP menjadi 2.700 orang dan adanya pengalihan anggaran balai diklat sebesar kurang lebih 60\% untuk penanganan Covid-19 sesuai PERPPU No 1 Tahun 2020 (BPN 2020) maka BDA KKP memilih metode diklat jarak jauh melalui metode e-learning. Pelatihan dengan metode e-learning mengacu pada surat edaran yang diterbitkan oleh Lembaga Administrasi Negara (LAN) nomor 10 tahun 2020 tentang panduan teknis penyelenggaraan pelatihan dalam masa pandemi corona virus disease (covid-19) (LAN 2020).

E-Learning merupakan metode pembelajaran jarak jauh dengan memanfaatkan teknologi informasi yaitu media elektronik dan jaringan internet dalam proses belajar mengajar atau pelatihan, dimana para peserta didik dan pelatihan dapat berpartisipasi kapanpun dan dimanapun. $E$ Learning dipandang sebagai metode yang lebih efektif, aman, dan nyaman untuk digunakan di tengah situasi PSBB yang diberlakukan oleh pemerintah saat ini. Pembelajaran dan pelatihan melalui e-learning menjadi populer di dunia pada masa pandemi covid-19 (Soni 2020), serta menjadi metode alternatif dan banyak digunakan oleh banyak pihak baik dari kalangan akademisi, profesional, perusahaan dan bahkan pemerintahan. Hal ini terlihat dari peningkatan jumlah penggunaan e-learning untuk kelas online, konferensi dan meeting. Berbagai lembaga telah melakukan pelatihan dengan metode e-learning dan membuktikan keefektifannya. Implementasi e-learning cukup efektif dalam meningkatkan pemahaman peserta terhadap materi pelatihan pada diklat yang dilaksanakan oleh Pusat Pelatihan dan Pengembangan dan Kajian Desentralisasi dan Otonomi Daerah (Puslatbang KDOD) Kalimantan (Rahman et al. 2020). Metode e-learning juga terbukti mampu meningkatkan kinerja para pegawai dari perusahaan seperti PT. Bank Central Asia (Permatasari et al. 2018). Selain itu, efektifitas metode e-learning juga dirasakan oleh para mahasiswa di perguruan tinggi di Indonesia. Para mahasiswa tetap dapat melakukan proses belajar tanpa merasa khawatir akan pandemi covid-19 (Pratiwi 2020). Menurut Allo (2020), melalui $e$ learning pada masa pandemi covid-19 sangat membantu proses pembelajaran. Selain itu, melalui e-learning biaya pelatihan lebih sedikit dibandingkan dengan pelatihan secara konvensional (Widhiartha 2009).

E-Milea (electronic millennial learning) merupakan platform pelatihan e-learning yang dikembangkan oleh BDA KKP dalam menyediakan Diklat bagi pengembangan kompetensi ASN KKP. Melalui platform ini ASN KKP dapat mengikuti diklat secara gratis dan mengakses materi pelatihan dengan mudah, sehingga dapat meningkatkan kompetensi melalui materi yang disediakan. E-Milea menyediakan berbagai materi diklat seperti pelayanan publik, budaya kerja, kewirausahaan dan teknis penyuluhan (KKP 2020). E-Milea telah diresmikan pada bulan Mei 2020 lalu dan telah digunakan untuk pelatihan ASN KKP dalam beberapa angkatan namun tingkat kepuasan peserta dalam penggunaan aplikasi belum dievaluasi. Menurut Cidral et al. (2017) kepuasan peserta merupakan faktor penentu kesuksesan penggunaan suatu metode e-learning dan kepuasan pengguna dapat dievaluasi dengan memperhatikan beberapa variabel seperti kualitas sistem, kualitas informasi, dan kualitas layanan. Penelitian lain juga telah memaparkan bahwa kepuasan pengguna dipengaruhi oleh ketiga variabel tersebut (Machado da silva et al. 2014). Setiap variabel menjelaskan teknologi dan materi pada e-learning. Kualitas sistem memperlihatkan bagaimana penampilan dan karakteristik dari teknologi yang digunakan, kualitas informasi menjelaskan validasi, keakuratan dan kelengkapan isi sistem, dan kualitas layanan menggambarkan bagaimana responsibilitas, empati, dan keamanan sistem. Evaluasi kepuasan peserta sangat diperlukan untuk keberlangsungan program $e$ learning diklat BDA KKP, maka tujuan penelitian ini adalah mengalisis pengaruh implementasi sistem pelatihan e-learning terhadap tingkat kepuasan peserta Diklat melalui penggunaan aplikasi $e$-Milea.

\section{KAJIAN PUSTAKA DAN PEGEMBANGAN HIPOTESIS}

Kepuasan pengguna dalam memanfaatkan suatu sistem sangat berkaitan erat dengan keberhasilan sistem tersebut. Kepuasan pengguna lebih menyangkut pandangan pengguna terhadap sistem informasi, bukan pada aspek kualitas teknik sistem yang bersangkutan. Kepuasan pengguna sistem lebih mengukur persepsi hal-hal yang tersedia pada sistem informasi dari pada memberi informasi mengenai kemampuan fungsional sistem informasi tersebut (Guimares, Staples, dan Mckeen 2003; Pawirosumarto 2016). Pawirosumarto (2016) menjelaskan bahwa keberhasilan dimensi kepuasan pengguna merupakan tingkat kepuasan pengguna saat menggunakan sistem informasi. Hal ini merupakan salah satu langkah yang paling penting dari kesuksesan suatu sistem informasi. Kepuasan pengguna dari sistem informasi dapat dinilai 
dengan menggunakan kriteria, effectiveness, efficiency, overall satisfaction (Pawirosumarto, Katidjan, dan Mulyanto 2015; Dreheeb, Basir, dan Fabil 2016), enjoyment, information satisfaction, system satisfaction (Gable, Sedera, dan Chan 2008; Pawirosumarto 2016).

Kualitas sistem sebagai karakteristik penting dari persepsi pengguna untuk menggunakan teknologi informasi kemudian mengarah pada dampak positif langsung terhadap kepuasan pengguna (DeLone dan McLean 2003; Freeze et al. 2019). Berdasarkan prespektif pengguna, ada beberapa atribut dan fungsi yang dapat berdampak pada penggunaan e-learning seperti kegunaan, keandalan, dan efisiensi yang memenuhi dan dikategorikan dalam kualitas sistem dan menjadi atribut teratas dalam banyak model penelitian (Dreheeb, Basir, dan Fabil 2016). Reliability, ease of use, flexibility, dan functionality juga merupakan ukuran kualitas sistem (DeLone dan McLean 2003; Indriani dan Reza 2009). Indriani dan Reza (2009) membuktikan bahwa reliability, flexibility, functionality mempengaruhi kepuasan pengguna sistem. Pengguna sistem e-learning merasa puas apabila sistem e-learning memiliki panduan yang mudah dipahami, materi yang disajikan sesuai dengan kebutuhan pembelajaran, sistem mudah dioperasikan, mudah diakses fiturnya, dan mengintensifkan komunikasi pengajar dan mahasiswanya (Pawirosumato et al. 2015; Yuwono 2018).

Kemudahan pemakaian menjadi faktor utama yang berpengaruh terhadap kepuasan pengguna sistem (2011). Persepsi kemudahan penggunaan merupakan persepsi pengguna terhadap kemudahan yang diperoleh dari suatu adopsi sistem informasi. Faktor ini mempengaruhi perilaku pengguna sistem informasi yang kemudian berdampak pada perilaku individu dalam mengadopsi sistem informasi (Arbaugh 2002; 2011). Cidral et al. (2017) menyatakan bahwa apabila sistem e-learning mudah dinavigasi dan terstruktur dengan baik dalam hal konten dan fungsionalitas maka akan meningkatkan kepuasan dan penggunaan sistem elearning. Kualitas sistem informasi adalah karakteristik dari informasi yang melekat mengenai sistem itu sendiri sebagai perceived ease of use yang merupakan tingkat seberapa besar teknologi komputer dirasakan relatif mudah untuk dipahami dan digunakan. Hal ini menunjukkan jika pemakai sistem informasi merasa mudah dalam penggunaan sistem tersebut maka mereka tidak memerlukan banyak waktu dan tenaga untuk menggunakannya sehingga mereka merasa puas (Pawirosumarto 2016). Kendala minimal yang dimiliki oleh suatu aplikasi e-learning dapat mempermudah penggunaan oleh pengguna dan berdampak pada meningkatnya kepuasan dari pengguna (Harris dan Affandi 2011).

\section{$\mathrm{H}_{1}$ : Kualitas sistem berpengaruh positif signifikan terhadap kepuasan pengguna e-learning}

Kualitas informasi adalah nilai yang didapatkan oleh pengguna akhir sesuai dari informasi yang memiliki karakteristik isi, bentuk dan waktu (Larasati dan Andayani 2019). Kualitas informasi mengacu pada ukuran output sistem secara tradisional, yaitu sistem menghasilkan informasi utamanya dalam bentuk laporan. Karakteristik kualitas informasi yang diinginkan dalam sistem antara lain: accuracy, precision, currency, reliability, completeness, conciseness, relevance, understandbility, meaningfulness, timeliness, comparability, dan format (Swaid dan Wigand 2009; Freeze et al, 2019). Kualitas informasi melingkupi konten pada e-learning. Tujuan dasar dari system e-learning adalah menyediakan informasi pembelajaran bagi siswa (Bhatti, Bouch, dan Kuchinsky 2000; Freeze et al. 2019). Keakuratan informasi dan fitur akan mempengaruhi penerimaan pengguna (Lin dan Liu 2000; Freeze et al. 2019). Informasi penting untuk selalu diperbarui dengan gagasan sistem yang adaptif (Freeze et al. 2019). Kepuasan pengguna juga dipengaruhi oleh umpan balik yang diterima dalam pembelajaran (Rossin, et al. 2008; Freeze et al. 2019) dan umpan balik tersebut dapat dilihat sebagai elemen kualitas informasi. Tingkat kepuasan pengguna akan tumbuh apabila kualitas informasi yang sesuai dengan keperluan dan kebutuhan pengguna, informasi yang diberikan oleh sistem dapat dipercaya, dan informasi yang diberikan selalu up to date (Wijaya dan Suwastika 2017)

Fitur pembelajaran berkaitan dengan kegunaan keseluruhan fitur e-learning dan pengaturan materi pembelajaran menjadi komponen yang logis dan dapat dimengerti. Unsur-unsur informasi ini, mempengaruhi tingkat kepuasan, penggunaan sistem dan hasil pembelajaran (Eom, Wen, dan Ashill 2006; Freeze et al. 2019). Pawirosumarto, Katidjan, dan Mulyanto (2015) dalam penelitiannya menunjukkan bahwa terdapat hubungan yang searah antara kepuasan pengguna dengan kualitas informasi, yaitu semakin tinggi kualitas informasi yang disediakan, sistem e-learning semakin baik dan akan semakin tinggi pula tingkat kepuasan pengguna sistem e-learning. $\mathrm{Hal}$ ini mengindikasikan bahwa informasi yang 
disediakan oleh perguruan tinggi berkualitas dan bermanfaat bagi penggunanya maka pengguna akan merasa puas terhadap sistem. Jika sistem $e$ learning menyediakan rincian terkait materi perkuliahan, menyediakan kejelasan materi perkuliahan, tepat waktu dalam menyajikan informasi, dan memberikan penilaian yang akurat maka pengguna akan merasa puas dalam menggunakan sistem.

E-learning memiliki salah satu fitur khusus yang dapat memudahkan pengguna dan mempengaruhi kepuasan pengguna yaitu kesesuaian konten (Clark, 2002; Harris dan Affandi 2011). Konten harus relevan atau sesuai dengan tujuan pembelajaran tersebut (kesesuaian konten) sehingga didapatkan hasil yang maksimal dalam pemanfaatan e-learning. (Yuwono 2018) menyatakan bahwa sistem e-learning yang menyediakan informasi tepat dan akurat, sesuai dengan kebutuhan informasi yang diperlukan oleh pengguna, disesuaikan juga dengan kebutuhan pada kantor, informasi yang diberikan selalu informasi yang baru, dan peserta memahami setiap informasi yang tersedia pada sistem merupakan e-learning yang efektif.

\section{$\mathrm{H}_{2}$ : Kualitas informasi berpengaruh positif signifikan terhadap kepuasan pengguna}

Kualitas layanan sistem adalah suatu pelayanan yang disediakan pada sistem untuk pengguna dari pengembang sistem yang berbentuk update sistem informasi dan tanggapan dari pengembang mengenai masalah yang terjadi pada sistem informasi (Larasati dan Andayani 2019). Kualitas layanan cukup baik apabila layanan yang diterima sesuai dengan harapan. Demikian sebaliknya, sistem informasi tersebut buruk apabila layanan yang diterima tidak sesuai harapan (Pawirosumarto, Katidjan, dan Mulyanto 2015). Penelitian yang dilakukan Pawirosumarto, Katidjan, dan Mulyanto (2015) menunjukkan bahwa terdapat hubungan positif antara kualitas layanan dengan kepuasan pengguna. Sistem $e$ learning yang menyediakan layanan proses download materi perkuliahan yang cepat, penilaian hasil pembelajaran online yang setara dengan pembelajaran konvensional, dan kemudahan menghubungi pengelola saat menemui masalah dalam akses ke sistem e-learning akan meningkatkan kepuasan pengguna sistem.

Fitur khusus lain yang dimiliki oleh $e$ learning yang dapat mempengaruhi kepuasan pengguna yaitu penggunaan metode instruksional agar materi yang disampaikan lebih dipahami oleh pengguna. E-learning juga memiliki fitur khusus yaitu penggunaan elemen media seperti gambar dan kalimat untuk menyampaikan metode dan konten pembelajaran yang membantu dalam penyampaian materi yang diberikan. Elemen media juga membantu pengguna dalam melakukan akses data yang terdapat pada $e$ learning dan juga membuat tampilan sistem menjadi lebih menarik (Clark 2002; Harris dan Affandi 2011). Pembelajaran e-learning yang menggunakan metode evaluasi yang beragam dipersepsikan oleh pengguna sebagai bentuk interaksi mahasiswa dengan dosen dan merupakan upaya mereka untuk memperoleh penilaian secara memadai dalam proses pembelajaran (Harris dan Affandi 2011). Studi kasus yang dilakukan Cidral et al. (2017) menunjukkan bahwa jika sistem $e$ learning menyediakan berbagai cara untuk penilaian pembelajaran atau evaluasi melalui kuis, tes, dan cara lain menguji pengetahuan serta pengguna e-learning dapat berinteraksi satu sama lain, maka hal ini akan mengarah pada peningkatan kepuasan.

\section{$\mathrm{H}_{3}$ : Kualitas layanan berpengaruh positif signifikan terhadap kepuasan pengguna}

\section{METODE PENELITIAN}

Upaya pencapaian target jumlah ASN KKP yang harus dilatih secara online oleh BDA KKP melalui e-Milea menjadi alternatif pengganti diklat konvensional (tatap muka) di masa pandemi Covid-19. Demi keberlanjutan program e-learning ini maka evaluasi atas penerapannya penting dilakukan guna mengetahui seberapa besar keberhasilannya, dan hasil evaluasi dijadikan sebagai pedoman untuk memperbaiki sistem $e$ Milea di BDA KKP. Evaluasi dilakukan melalui penelitian untuk meningkatkan kepuasan para pengguna e-Milea kedepannya. Variabel kualitas sistem, kualitas informasi, dan kualitas layanan dijadikan dasar penilaian kepuasan pengguna $e$ Milea di BDA KKP. Variabel dalam penelitian ini terdiri dari 3 variabel independen dan 1 variabel dependen. Variabel independen terdiri dari variabel kualitas sistem (X1), kualitas informasi (X2), dan kualitas layanan (X3) sedangkan variabel kepuasan (Y1) pengguna menjadi variabel dependen.

Penilaian kepuasan dilakukan melalui pembagian kuisioner yang berisi pertanyaanpertanyaan mengenai kualitas materi, media, dan sistem e-learning kepada peserta Diklat Kewirausahaan angkatan kedua dan ketiga melalui platform evaluasi di e-Milea yang diisi peserta setelah mengikuti Diklat. Responden memberikan penilaian atas pengalamannya dalam menggunakan e-Milea dalam bentuk penilaian skala likert 1 sampai 4 (1: Sangat setuju - 4: tidak 
setuju) yang menunjukkan tingkatan persetujuan peserta terhadap sistem e-Milea. Pengumpulan data dilakukan terhadap peserta pelatihan $e$ learning gelombang kedua dan ketiga, mengingat gelombang pertama merupakan masa percobaan, sehingga datanya tidak dijadikan bahan analisis. Data hasil kuisioner diolah dan dianalisis dengan menggunakan SEM (Structural Equation Modelling) dengan bantuan software SmartPLS 3.0 untuk menguji signifikansi hipotesis tiga variabel yang diajukan, yaitu:

$\mathrm{H}_{01}$ : kualitas sistem tidak berpengaruh positif signifikan terhadap kepuasan pengguna

$\mathrm{H}_{11}$ : kualitas sistem berpengaruh positif signifikan terhadap kepuasan pengguna

$\mathrm{H}_{02}$ : kualitas informasi tidak berpengaruh positif signifikan terhadap kepuasan pengguna

$\mathrm{H}_{12}$ : kualitas informasi berpengaruh positif signifikan terhadap kepuasan pengguna

$\mathrm{H}_{03}$ : kualitas layanan tidak berpengaruh positif signifikan terhadap kepuasan pengguna

$\mathrm{H}_{13}$ : kualitas layanan berpengaruh positif signifikan terhadap kepuasan pengguna.
Berdasarkan hipotesis yang dibangun maka model penelitian ini dapat dilihat pada Gambar 1 . SEM terdiri dari 2 pengujian yaitu outer model dan inner model. Hasil pengujian terdiri dari 2 bagian, yaitu outer model dan inner model. Outer model digunakan untuk mengetahui validitas dan reliabilitas dari kuesioner sedangkan inner model digunakan untuk menguji hipotesis yang telah dibangun. Indikator yang lolos uji validitas adalah indikator yang memiliki nilai loading factos lebih besar dari 0,7. Jika terdapat nilai loading factor yang kurang dari o,7 maka indikator tersebut dapat dikeluarkan dari model. Tahap selanjutnya adalah uji reliabilitas. Variabel dapat dikatakan lolos uji reliabiltas jika nilai Cronbach's Alpha lebih besar daripada 0,7 dan Average Variance Extracted (AVE) lebih besar dari 0,5. Apabila salah satunya belum terpenuhi maka variabel tersebut belum lolos uji reliabilitas. $\mathrm{H}_{0}$ akan ditolak apabila $p$ value dari hasil inner model kurang dari 0,05 .

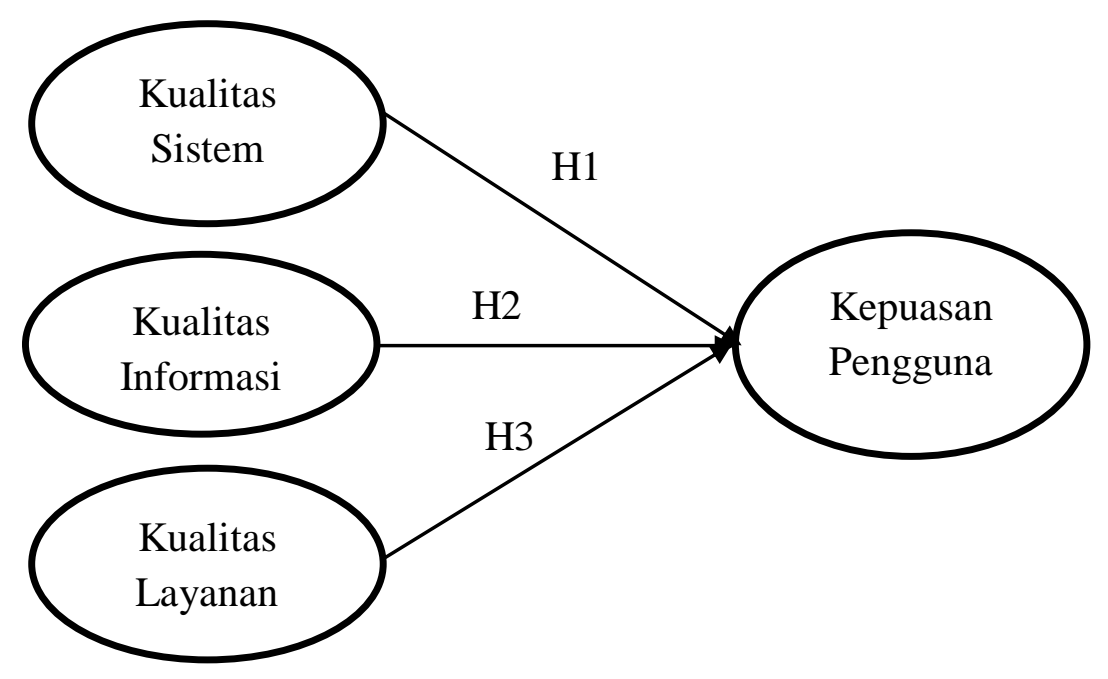

Gambar 1. Model Penelitian

\section{HASIL DAN PEMBAHASAN}

Jumlah peserta Diklat sebanyak 97 orang melalui e-Milea merupakan peserta Diklat Kewirausahaan Angkatan 2 dan 3 dari Direktorat Jenderal Perikanan Budidaya (DJPB) dan Direktorat Jenderal Penguatan Daya Saing Produk Kelautan dan Perikanan (Ditjen PDSPKP). Hasil kuesioner ini akan menjadi bahan evaluasi bagi BDA KKP untuk meningkatkan kepuasan dari para peserta diklat. Hasil dari kuesioner terdiri dari 20 pertanyaan yang mewakili 4 variabel laten. Setiap variabel terdiri dari 5 indikator yang diajukan kepada para peserta. Hasil uji validitas dari kuesioner yang telah dikumpulan dapat dilihat pada Tabel 1. Indikator dinyatakan valid apabila nilai outer loading lebih besar dari 0,7. Pada penelitian ini tidak semua indikator valid. Beberapa indikator tidak valid karena nilai loading factor kurang dari 0,7. Indikator tersebut antara lain X14, X15, dan X33. Setelah ketiga indikator tersebut dikeluarkan dari model, 17 indikator lainnya telah lolos uji validitas. Ketiga variabel independent juga telah lolos uji reliabilitas yang dapat diketahui dari nilai Cronbach's Alpha dan AVE yang lebih besar dari 0,7 dan 0,5 (Tabel 1).

Adjusted $R$ square dari model ini sebesar 0,793 atau $79,3 \%$. Nilai tersebut berarti bahwa variabel kualitas system, kualitas informasi, dan kualitas layanan dapat menjelaskan variabel 
kepuasan pengguna sebesar 79,3\% dan sisanya sebesar 20,7\% dijelaskan oleh variabel lain di luar penelitian. Goodness of Fit dari model dapat dihitung melalui persamaan 1. Hasil dari perhitungan GoF sebesar 0,724 sehingga model ini dapat fit atau model sesuai dengan data yang ada.

$$
\begin{aligned}
& \text { GoF }=\sqrt{\overline{A V E} \times \overline{R^{2}}} \\
& \text { GoF }=\sqrt{0,662 \times 0,793} \\
& \text { GoF }=0,724
\end{aligned}
$$

Indikator yang paling mampu merefleksikan variabel kualitas sistem adalah indikator X11 karena nilai loading factor X11 paling besar diantara ketiga indikator lainnya. Sehingga para peserta pelatihan diklat yang menggunakan $e$ Milea merasa kualitas sistem yang paling dibutuhkan adalah kemampuan sistem untuk menyediakan isi yang sesuai dengan kebutuhan peserta. Indikator X24 merupakan indikator yang paling baik untuk merefleksikan variabel kualitas informasi dengan nilai loading factor sebesar 0,842 . Indikator X24 menjelaskan bahwa para peserta membutuhkan infomasi yang mudah dipahami. Indikator yang mampu merefleksikan variabel kualitas layanan adalah indikator X34. Dimana indikator tersebut menjelaskan bahwa responden membutuhkan sistem e-learning yang mampu mengontrol kemajuan belajar mereka. Indikator yang paling mendominasi variabel kepuasan pengguna adalah Y11. Indikator tersebut menyatakan bahwa pengguna merasa puas karena kemampuan mereka meningkat setelah mengikuti pelatihan atau e-learning dengan $e$-Milea.

Tabel 1. Hasil uji validitas dan reliabilitas

\begin{tabular}{|l|r|l|l|l|l|}
\hline \multirow{2}{*}{ Indikator } & \multicolumn{2}{|c|}{ Validitas } & \multicolumn{3}{|c|}{ Reliabilitas } \\
\cline { 2 - 6 } & Loading Factor & Keterangan & Cronbach's Alpha & AVE & Keterangan \\
\hline X11 & 0,903 & Valid & & & \\
X12 & 0,898 & Valid & 0,866 & 0,788 & Reliable \\
X13 & 0,861 & Valid & & & \\
\hline X21 & 0,815 & Valid & & & \\
X22 & 0,816 & Valid & & \multirow{2}{*}{ Reliable } \\
X23 & 0,840 & Valid & 0,882 & 0,680 & \\
X24 & 0,842 & Valid & & & \\
X25 & 0,809 & Valid & & & \\
\hline X31 & 0,838 & Valid & & & \\
X32 & 0,830 & Valid & 0,871 & 0,721 & Reliable \\
X34 & 0,869 & Valid & & & \\
X35 & 0,858 & Valid & & & \\
\hline Y11 & 0,821 & Valid & & & \\
Y12 & 0,748 & Valid & & & \\
Y13 & 0,715 & Valid & 0,822 & 0,586 & Reliable \\
Y14 & 0,820 & Valid & & & \\
Y15 & 0,717 & Valid & & & \\
\hline
\end{tabular}

Hasil pengujian inner model dapat dilihat pada Gambar 2. Kualitas sistem berhubungan positif terhadap kepuasan pengguna yang dilihat dari nilai original sample yang positif yaitu 0,384 . Pengaruh kualitas sistem terhadap kepuasan pengguna sangat signifikan yang dapat diketahui dari $\mathrm{p}$ value yang kurang dari 0,05 yaitu sebesar 0,006 dan t-statistics yang lebih besar dari 1,96 yaitu sebesar 2,754 (Tabel 2). Sehingga kualitas sistem berpengaruh positif signifikan terhadap kepuasan pengguna. Ketika kualitas sistem ditingkatkan $100 \%$ maka akan meningkatkan kepuasan pengguna sebesar 38,4\%. Hasil penelitian ini sesuai dengan Freeze et al. (2009) dan Pawirosumarto (2016) bahwa kualitas sistem akan mempengaruhi tingkat kepuasan dari pengguna. Ramayah dan Lee (2012) juga menjelaskan bahwa kualitas sistem akan mempengaruhi tingkat kepuasan pengguna dan untuk menggunakan sistem e-learning. Reliability dan functionality menjadi kebutuhan sistem yang harus dipenuhi oleh BDA KKP. Karena sistem yang mampu memberikan informasi yang andal, up to date, dan sesuai dengan kebutuhan 


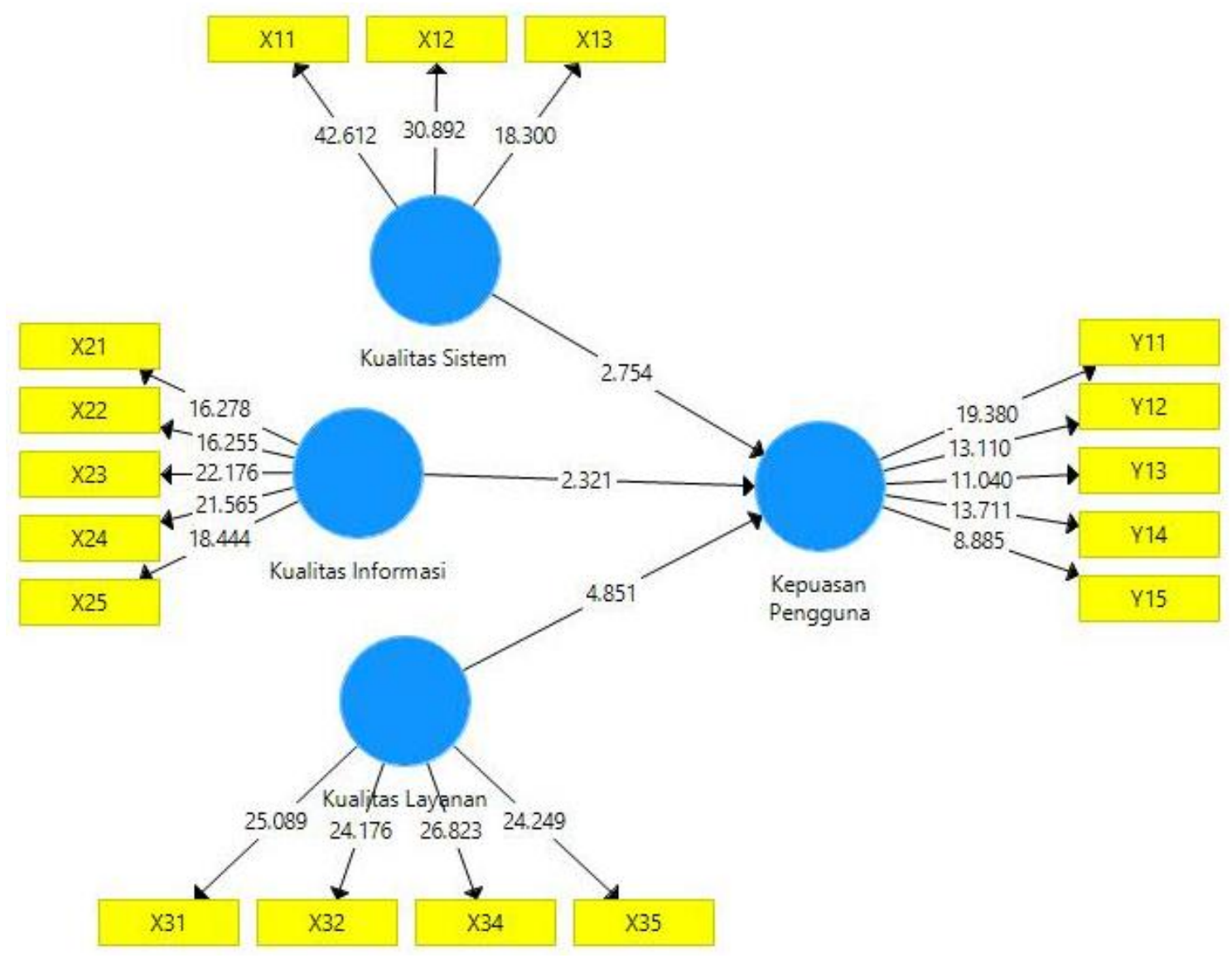

Gambar 2. Hasil inner model penelitian

Hasil pengujian inner model dapat dilihat pada Gambar 2. Kualitas sistem berhubungan positif terhadap kepuasan pengguna yang dilihat dari nilai original sample yang positif yaitu 0,384 . Pengaruh kualitas sistem terhadap kepuasan pengguna sangat signifikan yang dapat diketahui dari $\mathrm{p}$ value yang kurang dari 0,05 yaitu sebesar 0,006 dan t-statistics yang lebih besar dari 1,96 yaitu sebesar 2,754 (Tabel 2). Sehingga kualitas sistem berpengaruh positif signifikan terhadap kepuasan pengguna. Ketika kualitas sistem ditingkatkan $100 \%$ maka akan meningkatkan kepuasan pengguna sebesar 38,4\%. Hasil penelitian ini sesuai dengan Freeze et al. (2009) dan Pawirosumarto (2016) bahwa kualitas sistem akan mempengaruhi tingkat kepuasan dari pengguna. Ramayah dan Lee (2012) juga menjelaskan bahwa kualitas sistem akan mempengaruhi tingkat kepuasan pengguna dan untuk menggunakan sistem e-learning. Reliability dan functionality menjadi kebutuhan sistem yang harus dipenuhi oleh BDA KKP. Karena sistem yang mampu memberikan informasi yang andal, up to date, dan sesuai dengan kebutuhan responden akan meningkatkan kepuasan pengguna e-Milea.

Kualitas informasi juga berpengaruh positif signifikan terhadap kepuasan pengguna $e$-Milea $(p$ value $<0,5$; $t$-statitics $>1,96$ ). Untuk itu, jika pelatihan diklat KKP mampu meningkatkan kualitas informasi sebesar $100 \%$ akan meningkatkan kepuasan pengguna sebesar $27,3 \%$. Hasil ini mendukung hasil penelitian dari Cidral et al. (2017) bahwa kepuasan pengguna e-learning dipengaruhi oleh kualitas informasi. E-learning yang mampu menyiapkan materi yang sesuai dengan tujuan diklat, kualitas bahan ajar yang baik, dan informasi yang mudah dipahami akan meningkatkan kepuasan pengguna e-Milea. Yuwono (2018) menyatakan bahwa informasi yang diberikan harus sesuai dengan tujuan dan informasi tersebut tepat serta akurat. Kualitas informasi yang baik mampu meningkatkan kepuasan pengguna dan meningkatkan loyalitas pengguna e-learning (Wang dan Chiu 2011). Kualitas layanan juga perlu diperhatikan karena variabel ini berpengaruh positif signifikan terhadap kepuasan pengguna ( $p$ value sebesar 0,000 dan $t$-statistics sebesar 4,851). Ketika $e$ - 
Milea mampu memberikan respon dengan cepat kepada pengguna maka hal tersebut mampu meningkatkan kepuasan pengguna. Ketika kualitas pelayanan e-Milea ditingkatkan 100\% maka akan mampu meningkatkan kepuasan pengguna sebesar $35,2 \%$ secara signifikan. Wang dan Chiu (2011) juga menyatakan bahwa salah satu penyebab pengguna e-learning merasa puas adalah kualitas layanan. Tak hanya kepuasan pengguna, peningkatan kualitas pelayanan $e$ learning akan meningkatkan loyalitas pengguna $e$ learning (Wang dan Chiu 2011). Cidral et al. (2017) menjelaskan bahwa kualitas layanan dapat memberikan kuis atau penugasan yang melibatkkan peserta pelatihan. Kuis-kuis tersebut juga dapat mengetahui kefahaman dari para peserta pelatihan.

Tabel 2. Original sample, sample mean, standard deviation, $T$-statistics, dan $p$ value dari inner model

\begin{tabular}{|l|r|r|r|r|l|}
\hline \multicolumn{1}{|c|}{ Variable } & $\begin{array}{c}\text { Original } \\
\text { Sample }(\beta)\end{array}$ & $\begin{array}{c}\text { Sample } \\
\text { Mean }\end{array}$ & $\begin{array}{c}\text { Standard } \\
\text { Deviation }\end{array}$ & $\begin{array}{c}T \\
\text { Statistics }\end{array}$ & P Values \\
\hline Kualitas Layanan -> Kepuasan Pengguna & 0,352 & 0,357 & 0,072 & 4,851 & $0,000^{* *}$ \\
\hline $\begin{array}{l}\text { Kualitas Informasi -> Kepuasan } \\
\text { Pengguna }\end{array}$ & 0,273 & 0,294 & 0,118 & 2,321 & $0,021^{*}$ \\
\hline Kualitas Sistem -> Kepuasan Pengguna & 0,384 & 0,36 & 0,139 & 2,754 & $0,006^{* *}$ \\
\hline
\end{tabular}

Sig: 0,01 “**”; 0,05 “*”

Ketiga tipe kualitas yang telah dijelaskan di atas berpengaruh terhadap tingkat kepuasan pengguna e-learning. Harapannya $\mathrm{BDA} \mathrm{KKP}$ dapat memperhatikan kualitas sistem, kualitas informasi, dan kualitas layanan yang ada pada $e$ Milea. Apabila ada salah satu kualitas tersebut menurun maka kepuasan pengguna akan menurun. Penurunan kepuasan pengguna akan menurunkan minat pengguna untuk menggunakan e-learning tersebut (Liaw 2008; Wang Chiu 2011). Apalagi kondisi pandemi yang sedang terjadi, menuntut kita untuk percepatan proses digitalisasi. Salah satunya pelatihan atau diklat. Di berbagai negara maju, pelatihan sudah berbasis digital. Sehingga keterbatasan jarak menjadi sesuatu yang dapat diminimalisir. Selain itu, biaya yang digunakan untuk menyelenggarakan pelatihan berbasis $e$ learning menjadi lebih murah. Waktu pelatihan yang fleksibel membantu meningkatkan kepuasan pengguna. Karena tidak semua peserta dapat hadir di waktu yang telah ditentukan. Berdasarkan penjelasan di atas kualitas sistem, kualitas informasi, dan kualitas layanan menjadi faktor utama yang dapat mempengaruhi tingkat kepuasan pengguna $e$-Milea. Ketika BDA KKP mampu mempertahankan atau meningkatkan kepuasan pengguna maka ketertarikan pengguna untuk terus menggunakan e-Milea juga akan meningkat. Kemampuan institusi meningkatkan kepuasan pengguna akan memperkuat implementasi e-learning.

\section{KESIMPULAN}

Kualitas sistem, kualitas informasi, dan kualitas layanan menjadi kunci utama dari kepuasan pengguna e-Milea. Ketika BDA KKP dapat meningkatkan kualitas sistem, kualitas informasi, dan kualitas layanan maka kepuasan pengguna $e$-Milea juga akan meningkat. Hal ini dikarenakan kualitas sistem, kualitas informasi, dan kualitas layanan berpengaruh positif signifikan terhadap kepuasan pengguna. Kepuasan pengguna yang meningkat akan mempengaruhi niat pengguna e-Milea untuk kembali menggunakan sistem tersebut. Salah satu cara untuk memperkuat implementasi e-learning adalah dengan meningkatkan kepuasan pengguna.

\section{REFERENSI}

Allo, Markus Deli Girik. "Is The Online Learning Good in the Midst of Covid-19 Pandemic? The Case of EFL Learners." Jurnal Sinestesia 10, No. 1 (2020). https://sinestesia.pustaka.my.id/journal/artic le/view/24

Arbaugh, J. Ben. "Managing the on-line classroom: A study of technological and behavioral characteristics of web-based MBA courses." The Journal of High Technology Management Research 13, no. 2 (2002): 203-223. https://doi.org/10.1016/S10478310(02)00049-4

Badan Pertahanan Nasional (BPN). "Peraturan Pemerintah Republik Indonesia Nomor 21 Tahun 2020." Last modified June 30, 2020, https://www.atrbpn.go.id/Publikasi/

Peraturan-Perundangan/peraturanpemerintah-republik-indonesia-nomor-21tahun-2020-121618

Badan Pertahanan Nasional (BPN). "Peraturan Pemerintah Pengganti Undang-Undang Republik Indonesia Nomor 1 Tahun 2020.” 
Last modified June 30, 2020. https://www.atrbpn.go.id/Publikasi/Peratura n-Perundangan/Perpu/peraturan-

pemerintah-pengganti-undang-undangrepublik-indonesia-nomor-1-tahun-2020121620

Badan Administrasi Negara (LAN). "Panduan Teknis Penyelenggaraan Pelatihan dalam Masa Pandemi Coronavirus Disease (Covid-19)." Last modified July 2, 2020. http://ppid.lan.go.id/?p=3666

Bhatti, Nina, Anna Bouch, and Allan Kuchinsky. "Integrating user-perceived quality into web server design." Computer Networks 33, no. 1-6 (2000): 1-16.

Cidral, Wilmar Audye, Tiago Oliveira, Massimo Di Felice, and Manuela Aparicio. "ELearning Success Determinants: Brazilian Empirical Study." Computers \& Education 122 (2018): 273-290. https://doi.org/10.1016/j.compedu.2017.12. 001.

Clark, Ruth. "Six principles of effective eLearning: What works and why." The elearning developer's Journal 6, no. 2 (2002): 1-10.

Delone, William H., and Ephraim R. McLean. "The DeLone and McLean model of information systems success: a ten-year update." Journal of management information systems 19, no. 4 (2003): 9-30. https://doi.org/10.1080/07421222.2003.110 45748

Dreheeb, Abdulhakim Elmoawe, Nurlida Basir, and Norasikin Fabil. "Impact of system quality on Users' satisfaction in continuation of the use of E-learning system." International Journal of $e$ Education, e-Business, e-Management and e-Learning 6, no. 1 (2016): 13-20. https://doi.org/

10.17706/ijeeee.2016.6.1.13-20

Eom, Sean B., H. Joseph Wen, and Nicholas Ashill. "The determinants of students' perceived learning outcomes and satisfaction in university online education: An empirical investigation." Decision Sciences Journal of Innovative Education 4, no. 2 (2006): 215-235.

Freeze, Ronald D., Khaled A. Alshare, Peggy L. Lane, and H. Joseph Wen. "IS success model in e-learning context based on students' perceptions." Journal of Information systems education 21, no. 2 (2019): 4.

Gable, Guy G., Darshana Sedera, and Taizan Chan. "Re-conceptualizing information system success: The IS-impact measurement model." Journal of the association for information systems 9 , no. 7 (2008): 377-408.

Guimaraes, Tor, D. Sandy Staples, and James D. Mckeen. "Empirically testing some main user-related factors for systems development quality." Quality Management Journal 10, no. 4 (2003): 39-50. https://doi.org/10.1080/10686967.2003.119 19083

Harris, Lutfi, and Didied Poernawan Affandy. "Dimensi yang mempengaruhi kepuasan pengguna e-learning pada perguruan tinggi di Jawa Timur." Jurnal Akuntansi Multiparadigma 2, no. 3 (2011): 480-491. http://dx.doi.org/10.18202/jamal.2011.12.7 135

Indriani, Mirna, and Reza Adryan. "Kualitas Sistem Informasi Dan Kepuasan Pengguna Sistem Informasi Perguruan Tinggi Universitas Syiah Kuala." Jurnal Telaah dan Riset Akuntansi 2, no. 1 (2009): 79-92.

Kementerian Kelauatan dan Perikanan (KKP). "Panduan Pembelajaran E-Milea." Last modified June 28, 2020. https://kkp.go.id/ancomponent/media/upload-gambarpendukung/Balai\%20Diklat\%20Aparatur\% 20KKP/Panduan\%20Pembelajaran\%20E\% 20Milea\%20Update.pdf

Larasati, Niken Ayu, and Sri Andayani. "Pengaruh Penggunaan Learning Management System (LMS) Terhadap Tingkat Kepuasan Mahasiswa Menggunakan Metode DeLone and McLean." Jurnal Teknik Informatika UNIKA Santo Thomas 4, no. 1 (2019): 1320.

Lin, Judy Chuan-Chuan, and Hsipeng Lu. "Towards an understanding of the behavioural intention to use a web site." International journal of information management 20, no. 3 (2000): 197-208.

Machado-Da-Silva, Fabio Nazareno, Fernando de Souza Meirelles, Douglas Filenga, and Marino Brugnolo Filho. "Student satisfaction process in virtual learning system: Considerations based in information and service quality from Brazil's experience." Turkish Online Journal of Distance Education 15 no. 3 (2014): 122-142. https://doi.org/10.17718/tojde.52605

Pawirosumarto, Suharno. "Pengaruh kualitas sistem, kualitas informasi, dan kualitas layanan terhadap kepuasan pengguna sistem 
e-learning." MIX: Jurnal Ilmiah Manajemen 6, no. 3 (2016): 152864.

Pawirosumarto, Suharno, Purwanto S. Katidjan, and Angga Dwi Mulyanto. "Pengaruh Computer Self-Efficacy Terhadap Kualitas Sistem, Kualitas Informasi, Kualitas Layanan, Penggunaan, Kepuasan Pengguna, Dan Dampak Individu." MIX: Jurnal Ilmiah Manajemen 5, no. 2 (2015): 153818.

Permatasari, Indah, and Hardiyan. "Pengaruh Elearning Sebagai Media Pelatihan dan Pengembangan Terhadap Kinerja Karyawan BCA KCU Tangerang." Jurnal SISFOKOM 07, no 01 (2018): 1-8

Pratiwi, Ericha Windhiyana. "Dampak Covid-19 Terhadap Kegiatan Pembelajaran Online di Sebuah Perguruan Tinggi Kristen di Indonesia." Perspektif Ilmu Pendidikan 34, $\begin{array}{lll}\text { No. } & 1 & \text { (2020): }\end{array}$ http://doi.org/10.21009/PIP.341.1

Rahman, Muhammad Abdi, Rustan Amarullah, and Kemal Hidayah. "Evaluation of Elearning Models Implementation in Basic Training of Prospective Civil Servants." Jurnal Borneo Administrator 16, no 1 (2020): 101-116. doi: https://doi.org/10.24258/jba.v16i1.656

Ramayah, Thurasamy, and Jason Wai Chow Lee. "System characteristics, satisfaction and elearning usage: a structural equation model (SEM)." Turkish Online Journal of Educational Technology-TOJET 11, no. 2 (2012): 196-206.

Rossin, Don, Young K. Ro, Barbara D. Klein, and Yi Maggie Guo. "c." Journal of information systems education 20, no. 1 (2009).

Soni, Vishal Dineshkumar. "Global Impact of Elearning during COVID 19." SSRN Electronic Journal, June (2020). https://doi.org/ 10.2139/ssrn.3630073

Swaid, Samar I., and Rolf T. Wigand. "Measuring the quality of e-service: Scale development and initial validation." Journal of Electronic Commerce Research 10, no. 1 (2009): 13-28.

Wang, Hei Chia, and Yi Fang Chiu. "Assessing elearning 2.0 system success." Computers \& Education 57, no. 2 (2011): 1790-1800. https://doi.org/10.1016/j.compedu.2011.03. 009

Widhiartha, Putu Ashintya. "Pemanfaatan Elearning sebagai Alternatif Pengganti Pelatihan Tatap Muka bagi Pendidik dan Tenaga Kependidikan Pendidikan Nonformal." Jurnal Ilmiah VISI PTK-PNF 4, No.2 (2009): 189-196
Wijaya, I. Gusti Ngurah Satria, and I. Wayan Kayun Suwastika. "Analisis Kepuasan Pengguna E-Learning Menggunakan Metode Kano." Jurnal Sistem dan Informatika (JSI) 12, no. 1 (2017): 128-138.

World Health Organization (WHO). "Who Director-General's Opening Remarks at The Media Briefing on Covid-19 - 11 March 2020. Geneva: WHO; 11 March 2020." Last modified July 1, 2020. https://www.who.int/dg/speeches/detail/wh o-director-general-s-opening-remarks-atthe-media-briefing-on-covid-19---11march-2020

Yuwono, Imbuh. "Efektifitas E-Learning Pusdiklat BMKG Menggunakan Model Delone \& Mclean." Bina Manfaat Ilmu: Jurnal Pendidikan 1, no. 04 (2018): 220229. 